\title{
Experience and networked learning
}

\author{
Chris Jones, \\ School of Education, Liverpool John Moores University, c.r.jones1@ljmu.ac.uk
}

\begin{abstract}
This paper reviews the way experience has been understood and the research agendas associated with that understanding in networked learning. In the contemporary context the student 'experience' is part of common speech and often associated with a consumerist discourse, especially in the UK and US. The widespread use of digital and networked technologies in education has also given rise to a decentring of the subject and an identification of actors in network settings as hybrids of humans and machines (including software and code in this category) or including machines and objects as actors within a network. With a decentred subject does it still make sense to understand learning in terms of the subject's personal experience anymore?

This paper explores these debates in the context of current educational discourse and in relation to prior research and theory in networked learning. Experience has a long history associated with phenomenological research and the related but distinct approach of phenomenography. It is related to central issues for education and learning, in particular the place of the 'individual' cognising subject. Experience can be thought of as either the essential distinguishing component of the individual human subject, or experience can be understood as the subjective component of one kind of element in a wider assemblage of humans and machines. In the later understanding of experience in assemblages human experience does not separate the human actor from other actors in a network and they are understood symmetrically.

It is a long standing position that the human sciences have a different relationship to their objects of study than natural sciences because the human sciences can have access to interior accounts from the 'objects' they observe and because human subjects can behave in ways that are not predicable, replicable, and which depend on an active construction of experience in the world. For networked learning the position and role of the human subject is a central concern and human-human interaction has always been considered essential. This paper reasserts the need for a proper understanding of experience and explores the place of the human subject in the developing research agendas found in networked learning.
\end{abstract}

\section{Keywords}

Experience, student, subject, post-human, sociomaterial, phenomenology, phenomenography.

\section{Introduction}

The student experience has become a buzz word in Higher Education, especially in the more marketised US and UK systems. Students are regularly referred to as 'customers' and the student experience is measured in terms of 'satisfaction'. My own university recently remodelled its web site and included images of students and the city and a video to capture the 'student experience' at the institution (Figure 1)

The university is selling a vision of a life style as much as it is promoting an education, or as the strap line puts it: 'just studying for a degree'. Perhaps this is not surprising in England given that a typical student (on a threeyear course outside of London) might expect to graduate with around $£ 35,000-£ 40,000$ (48,000 Euro to 54,000 Euro) of debt in student loans (Bournsell 2015). This does not include interest charges which currently stand at $5.5 \%$ per annum. The experience of debt is currently one of the most defining aspects of the overall student experience in the UK and USA. This is not the same in other European countries (for example Germany has abolished fees) although a degree of marketisation can be found in many national HE systems (Altbach 2015). 


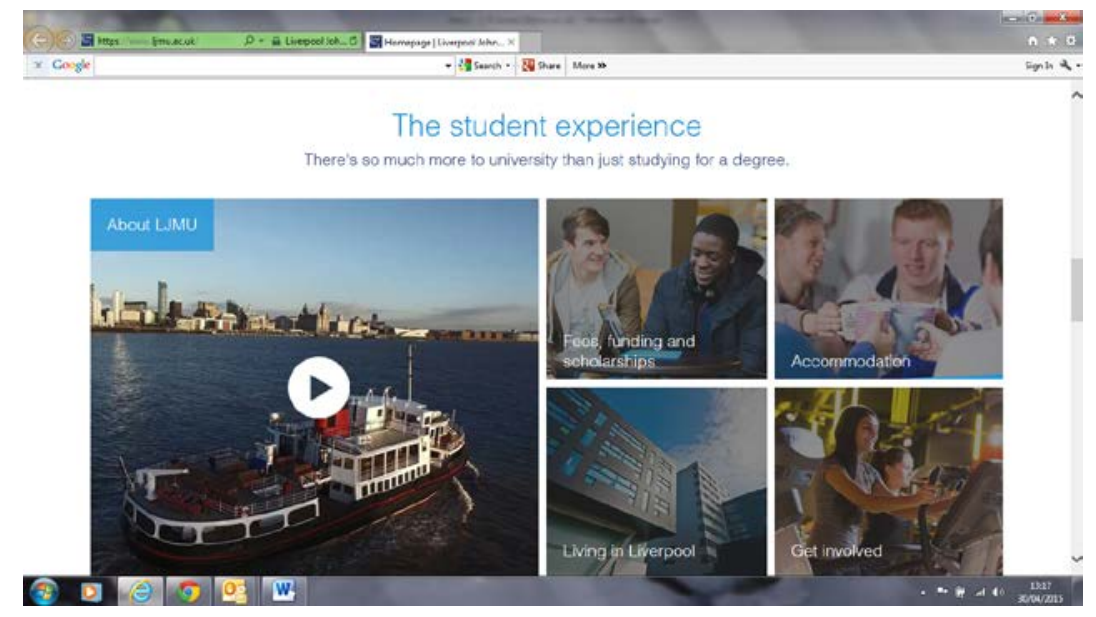

Figure 1 - The student experience: LJMU web site (redeveloped 2015)

Video link: https://youtu.be/Aps0mWnjBo0

The student experience is part of the competition that is encouraged by league tables ranking universities in national and international hierarchies (Sabri 2011). The student experience expressed in these tables has become part of the news cycle with 'success' in surveys and league tables being widely reported. There are now several international league tables that reflect national ambitions as well as the ambitions of specific institutions. This process gives rise to a peculiar kind of policy agenda in which universities are measured against each other with only the top 10, 50 or 100 places being deemed relevant (Hazelkorn 2015). An average performance and being an average institution which offers an average experience is now judged to be unacceptable - even though this is statistically irrational. Every university has an aim to be amongst the best and provide an excellent student experience. Institutions have formal mechanisms to monitor their league table performances and adjust their institutional policies to optimise their chances of improving their rankings. This competition between institutions is part of a process of the internationalisation and commodification of learning which valorises 'the' individual student experience and undermines the conception of education and learning as a benefit for all society (Altbach 2015).

It is in this context that this paper wishes to review and re-instate an older scholarly concern with the student experience, understood as a means of gaining insight into how the processes of networked learning are understood by those who participate in them. This longstanding interest has been associated with phenomenographic research in networked learning, using both qualitative and quantitative methods (see for examples Booth 2008, Cutajar 2012, Goodyear et al. 2005, Jones and Asensio 2001). There has also been a tradition that is more closely identified with phenomenology and a strong notion of what experience and student experience might entail (Dohn, 2006, 2014, Creanor et al. 2006).

\section{Individual experience}

Networked learning has an approach to learning which prioritises the connections between different elements and this attitude to learning is complimented by the relational approach found in phenomenography (Ellis and Goodyear 2010). Ference Marton described phenomenography as:

...the empirical study of the differing ways in which people experience, perceive, apprehend, understand, or conceptualize various phenomena in, and aspects of, the world around them (Marton, 1994, p4424).

The aim of phenomenographic research is to describe qualitatively different ways of experiencing phenomena (Marton and Booth, 1997). Phenomenography's non-dualist approach has generated an extensive literature concerning the learner experience (Marton et al., 1997, Ramsden, 2002). Experience in phenomenographic terms is the internal relationship constituted between persons and phenomena. This approach facilitates a second order research perspective and a focus on the experience of learning as opposed to learning itself (Marton, Dall'Alba, \& Beaty, 1993). The outcome of phenomenographic research is expressed in qualitative descriptions 
of the variations found in experiences of learning and this tradition is strongly associated with the idea of 'deep' and 'surface' learning (Haggis 2009).

Early work in networked learning informed by phenomenography attempted to include the lived experience of students in the discussions about technologies in education. A two year JISC funded project concerning students' experiences of networked learning (1999-2000) had a key role in formalising and stabilising the developing field of networked learning in continental Europe and the UK (Goodyear and Carvalho 2014). That project had as its main aim:

To help the UK HE sector come to a better understanding of the potential and problems of networked learning, particularly by attending to the student experience and to learning and teaching issues (Goodyear 2000 p3)

At that time there was a clear link drawn between networked learning and the student experience based on a relational view of learning and the phenomenographic tradition (see Jones and Asensio 2001).

Phenomenography allows for both a psychological (individual) and a social reading. For example Ellis and Goodyear argue that learning remains an individual process and that what goes on "between a person's ears" is important for the learning process (Ellis and Goodyear 2010: 6). They also argue for an ecological framework that locates student difficulties in a mismatch with their environment rather than as individual characteristics which are persistent, context free failings. Phenomenography stands distinct from specifically social and situated views of learning by locating itself in this more individualistic tradition. It also stands out as a distinct relational and monist approach that emphasises context dependence, rather than essential characteristics or styles. The location of the person- in-context opens phenomenography up to a social reading, in which personal characteristics are provisional and they can be altered by external interventions such as design, the use of technologies, social settings and environments. Phenomenography has a limited and disputed relationship with phenomenology (Hasselgren and Beach 1997) and in networked learning phenomenology has only had a limited development (Dohn, 2006, Oberg and Bell 2012).

The phenomenographic tradition has also provided a bridge between academic research and recent policy initiatives and practice. The quantitative branch of phenomenographic research developed a number of instruments (e.g. the approaches to study inventory (ASI) and the approaches and study skills inventory for students (ASSIST)), which went on to inform the development of national survey instruments deployed as part of public policy initiatives (Entwistle and Ramsden 1983, Haggis 2003, Sabri 2011). More broadly an understanding of learning in terms of approaches, conceptions, and outcomes has become an orthodox policy perspective in the UK and Australia and it has informed; the training of teachers in higher education, national student surveys, and government policies. The incorporation of approaches to learning research into educational policy has led to context specific elements of learning being fixed and generalised so that the relational aspect of the original approach has been lost (Haggis 2003, Sabri 2011).

The key ideas that phenomenography brought to networked learning were:

- A relational view of learning (non-dualist)

- An understanding that learning was context dependent

- A focus on how plans and actions were understood by participants

This clear focus on the relational nature of learning seems to have a natural connection with those theories of learning that emphasised the social context of learning which was another aspect of research strongly represented in networked learning.

\section{Social experience}

A key idea of constructivism is that knowledge is created by people, either as individuals or as part of groups, through experiencing the world and reflecting upon those experiences. Because knowledge is constructed by the knower from experience in the world it has a relational character and it does not exist externally and independently. Consequently knowledge cannot simply be transmitted and received. Constructivism can take individual or social forms but the most significant influence on networked learning has been through ideas related to social constructivism. In particular networked learning has drawn on social theories of learning including communities of practice (Lave and Wenger 1991, Wenger 1998) and activity theory (Engeström 2009). Dewey, a less explicit influence on networked learning, also emphasised action and experience (Dewey 1916 [1980]). Elkjaer set out Dewey's use of experience which he argued was distinct, but easily confused with more recent accounts of experience. 
Experience is both the process of experiencing and the result of the process. It is in experience, in transaction, that difficulties arise, and it is with experience that problems are resolved by inquiry. Inquiry (or critical and reflective thinking) is an experimental method by which new experience may be had not only through action but also by using ideas and concepts, hypotheses and theories as ‘tools to think with' in an instrumental way. (Elkjaer 2009 p75)

Building on a social view of learning, informed by Dewey's ideas, networked learning conceives of experience as a key aspect of the process of learning and in addition as a resource for researchers attempting to understand the ways networked learning is enacted through practice.

Lave contrasted her views with many of those associated with the term constructivism and the separation of the individual and cognitive in opposition to an external world. She also rejected the radical constructivist relativism in which the world is only subjectively or inter-subjectively constructed.

Learning, it seems to me, is neither wholly subjective nor fully encompassed in social interaction, and it is not constituted separately from the social world (with its own structures and meanings) of which it is part. This recommends a decentered view of the locus and meaning of learning, in which learning is recognized as a social phenomenon constituted in the experienced, lived-in world... (Lave 1991 p64)

It is this notion of learning as a social and cultural phenomenon constituted in the experienced, lived-in world that has been so influential in networked learning.

Whereas constructivism often makes a distinction between individual cognitive experiences and the environment in which the experience takes place socio-cultural approaches take a more phenomenological and monist approach to experience, understanding experience as being experience in the world (De Laat and Lally 2004). The emphasis in socio-cultural approaches is placed on learning constituted in joint activity, a process of participation in cultural practice(s), mutual exchange and dialogue. Technologies in these approaches are mediating 'tools' and cultural artefacts and the emphasis is placed on the cultural, social and organisational processes through which learning takes place. Subjective experience is understood as one aspect of practice, of activity in the world, inseparable from the non-subjective elements that may be experienced as external. Phenomenology and socio-cultural approaches both see tools as mediators of human experience and have a fundamentally asymmetrical understanding of their relationship (Kaptelinin and Nardi 2006). In socio-cultural theory humans and machines are distinct in character and cannot be treated as being alike.

Socio-cultural approaches have provided these key ideas in networked learning.

- Learning as a social and cultural activity

- Technology as a mediating aspect of human experience

- Intentionality and object orientation as key components of activity and experience

The socio-cultural approach has some key differences with other approaches that have become popular in networked learning, particularly actor-network theory (ANT) and post-humanism which tend to have a symmetrical understanding of the relationships between humans and technology in which heterogeneous networks of humans and machines are treated as various nodes in a network or as entanglements in an assemblage with humans and machines treated in the same way.

\section{Assemblages and experience}

Although related to social theories of learning ANT has its own distinct position, but this has been merged by some authors with other social theories of learning and post-humanism, and universalised as sociomaterialism (Fenwick and Edwards 2010, Fenwick et al. 2011). The use of the blanket term sociomaterialism is justified by the claim that all of the foundational theories for this approach (ANT, activity theory, post-humanism and complexity theory) conceptualise knowledge and capacities as being emergent from the webs of interconnections between heterogeneous entities, both human and non-human. Fox had previously drawn attention to the potential of ANT in relation to networked learning, but sociomaterialism has only recently become a mainstream concern in networked learning (Fox 2000, 2002, 2005, 2009). ANT and more broadly sociomaterialist approaches offer the prospect of being able to integrate the material technologies and media found in networked learning into a framework that encompasses people and machines in a symmetrical way. In an effort to bring Web technologies to critical enquiry, they are treated as key participants in this study. The participant list, therefore, included postings; avatars; tool bars; emoticons; archives; community member profiles; viruses; hyperlinks; the delete button; passwords and the technology that delivers postings, such as e-mail, discussion forum or RSS feed. Human actants include "newbies”, “wannabies", colleagues, "big names”, celebrities, competitors, posers, 
lurkers, employment recruiters, clients, friends, strangers and online paparazzi.” (Thompson

2012)

In this example technologies are introduced as component parts of lists that include both human and non-human participants that form assemblages - entanglements of actors in a symmetrical relationship. These assemblages are dynamic and components act upon each other to bring forth emergent properties that cannot be reduced to either context or individual cognition (Fenwick and Edwards 2011).

Learning understood from an ANT perspective is a network effect, it is neither understood as an essential cognitive process nor as a personal or social achievement (Fenwick and Edwards 2011).

...no agent or knowledge has an essential existence outside a given network: nothing is given in the order of things, but performs itself into existence. (Fenwick and Edwards 2011 p5)

Unlike other socio-cultural accounts sociomaterialism rests on a particular and peculiar kind of materialism (Harman 2009). The 'relational materiality' found in sociomaterialism understands matter not as discrete reified objects but as the effects of dynamic indeterminate processes. Sociomaterialism questions accepted categories such as individual and organization and many accepted binaries such as subject/object and knower/known. ANT clarifies how assemblages and entanglements are formed and how they hold together in associations that produce effects (Fenwick and Edwards 2011). Agency becomes an outcome of a network, a network effect and not an inherent (essential) property of any particular kind of agent, either human or machine. Humans, nonhumans, and hybrid combinations of the two, are all capable of exerting force and through their mutual interactions they co-constitute the effect of the assemblage.

Kaptelinin and Nardi (2006) capture different kinds of agency and different kinds of agent that arise in computing and computer networks. They distinguish between action when thought of as simply having an effect, and action which involves an intention. This distinction clearly separates their approach from ANT, despite the inclusion of activity theory as a contributing source to sociomaterialism. Kaptelinin and Nardi argue that despite the fact that different kinds of agents can exhibit similar agencies, humans and machines are distinct because of the object orientation and intention found in human activity. In this Kaptelinin and Nardi draw on the earlier work of Pickering who argued:

We [humans] construct goals that refer to presently nonexistent future states and then seek to bring them about. I can see no reason to suppose that DNA double helices or televisions organise their existence thus... (Pickering 1993 p566)

A problem I see with this formulation is that it relies on a clear distinction between people and machines, one which is often blurred in assemblages of both people and machines. It is conceivable that complex humanmachine networks may allow for the emergence of intentions which are neither the sole property of a single human nor of humans more generally. Assemblages can give rise to human-machine configurations that do have their 'own' needs, objects and most importantly intentions (Jones 2015). Subjective experience still resides in component parts [black boxes] of these assemblages and experience as a process and experience as an outcome both remain of interest for learning and for researchers of networked learning systems. The human form with a duration somewhere around 3 score and 10 years, remains a relatively stable entity that educators are keen to develop. The question addressed in this paper is: In what ways can networked learning think about and incorporate the idea of experience with regard to de-centred persons in the entanglements forming assemblages?

\section{The contemporary experience of being a student}

This paper argues that while the role of the subject and intentionality remains an important and distinguishing feature of human actors in human-machine assemblages, the significance of the experience of intentional actors is displaced in these configurations. Complex systems have an emergent character in which no single actor has a determining role (Clayton and Davies 2006). There are those that go on from this feature of emergence to suggest that outcomes in complex assemblages are consequences of an uncontrolled process; blind in the way that the evolutionary process takes place with no overall designer (Dennett 1995). I want to suggest otherwise and argue that in sociomaterial assemblages the conscious human element retains an important and at times decisive role, through a) design and b) intentional actions by socially located people, but one that needs to be seen as distinctly different from a reductive methodological individualism. In particular intentions are often enacted via organised entities in which the individual human actor is constrained by their social role and entangled in interactions with a variety of material forces which enable and constrain them. Within networks some nodes are more influential than others and over time patterns of entanglement in assemblages can produce effects that are persistent and instantiate power relations. While there may not be any single controller/point of control in such systems there are regulatory controls and some nodes in the network have considerable influence and a significant shaping role. 
The role for experience and intentional action that I argue for is especially relevant to education and networked learning in particular. The process described by ANT using the terms punctualisation and black boxing leads to forms of relative stability.

...the process of punctualization thus converts an entire network into a single point or node in another network (Callon 1991 p153).

This stability is a central concern in relation to a learner imbricated in a sociomaterial culture because the aim of education is to set up persistent patterns of practice and stable forms of awareness that prepare students for their futures, a supremely intentional activity. Human actors are formed in educational processes via their experiences. They become fashioned into stable forms but they remain malleable, in the memorable construction ascribed to the Jesuits - "Give me a child until they are seven and I'll give you the man (sic)". The human actor is constantly changing, but there remains a stubborn stability, a recognisable continuity over time in persons and personalities, across a range of contexts and through a myriad of experiences. This stability is not passive it rests on persistent intentional activity and active co-construction in various networks. Networked learning is interested in these interactive processes that co-constructively shape persons, and which provide characteristics that can be mobilised over a long period, if not a complete lifetime. Networked learning is also concerned with the culture of learning, both in the means which are used to shape persons and enrol people in their own shaping, and in the outcomes of that shaping. Learning in networked learning has a social and cultural form. In contemporary conditions when experience is standardised and homogenised into 'the' student experience it leads to a cultural and educational outcomes which reduce learning, and the learner, to measurable outputs that can be tabulated, ranked and processed by hidden codes and algorithms (Williams 2016). In contrast networked learning is interested in enabling diverse human experiences and a variety of often immeasurable outcomes.

An example of the way experience can play out in an assemblage of humans and machines comes from the use of a 'teacher bot' reported by Bayne (2015). The 'teacher bot' was developed by a team at the University of Edinburgh to provide a level of co-teaching within the massive open online course (MOOC) on 'E-learning and digital cultures'. It was part of an experimental course design which emphasised the development of critical understanding and explored a critical approach to educational automation. A developer built an automated teacher presence for the course Twitter feed which 'coded in' something of the teacher function so that it became less a question of a living teacher presence and more an assemblage of code, algorithm and teacher-student agency. In this work Student 4 recorded their experiences in this way:

the teacher bot led me on a merry chase looking up quotes and obscure academic references, which had the interesting side effect of 'ambush teaching' me. I will happily admit, that I do not feel like I have been to a class. I do not feel like I have been taught, either. I do, however, think I have learned something. I've certainly been prompted to think... (Bayne 2015: 463)

The questions this kind of approach inclines me think about are: Who/what prompted this thinking, who/what is the author of this experience? Within this assemblage the course was designed, the teacher bot developed and the student actively engaged. At all these points there are access points to the humans' experiences that can be used to inform future iterations of activity. Furthermore all the human activities display a future oriented intention. Although there is an assemblage of humans and machines there is additional access to the human actor in ways that the logs of machines or the presence of things do not provide and these humans are acting with a future objective informing their activities.

\section{Conclusion}

This paper has briefly reviewed the ways experience has been approached in networked learning and noted the ways in which this is distinct from the public discourse in which student experience is reified and homogenised into 'the' student experience as a gradable, numerical outcome. Networked learning is interested in experience because it provides an additional account from actors. These accounts are relevant for learning because they provide an insight into how human actors respond to the interactions they encounter in educational assemblages and the world more generally. The accounts also provide claims made by subjects about their intentions, setting out what they assert are their future oriented rationales for action. They are a source of evidence, information and inspiration that can be drawn on for design and understanding. Networked learning has been interested in experience as a source of knowledge about how human actors interpret the world they are interacting with and how they planfully engage in these interactions. The different approaches taken to research in networked learning, phenomenography, socio-cultural, and sociomaterial all take a relational view of learning but they differ in how they understand the human actor. 
The author argues that all actors cannot be treated as completely symmetrical for research purposes because of the access that we have to accounts of experience from human actors. This resource separates human actors from non-human actors including complex machines and the non-human parts of assemblages they are entangled in. Moreover the human actor, whether alone or acting as an agent of an organisation, is engaged in intentional and object oriented activity. The designer of a course or a technology anticipates the future and engages in the shaping of the entanglements that result from their designs. Other non-human actors do not and this provides an a priori separation of human actors from them. It is possible to envisage non-human actors that exhibit intentions and goal oriented activities, but in these cases evidence must be shown that this is the case and the activity engaged in is not simply a form of delegated agency. In summary this paper argues that networked learning research needs to retain a focus on human experience and to develop an empirical and theoretical understanding of how the decentred human experience in human-machine assemblages can help in the design and development of successful learning networks.

\section{References}

Altbach, P. (2015). Knowledge and education as international commodities. International higher education, (28), 2-5.

Bayne, S. (2015). Teacherbot: interventions in automated teaching. Teaching in Higher Education, 20 (4), 455467.

Booth, S. (2008).Researching Learning in Networked Learning-Phenomenography and Variation theory as empirical and theoretical approaches. In V. Hodgson, C. Jones, T. Kargidis, D. McConnell, S. Retalis, D. Stamatis \& M. Zenios (eds) Proceedings of the Sixth International Conference on Networked Learning, Halkidiki, Greece. Lancaster: Lancaster University: 450-455. Online HTTP < http://networkedlearningconference.org.uk/past-proceedings/index.htm>

Bournsell, P. (2015). Student finance. Online HTTP < http://university.which.co.uk/advice/student-finance/howmuch-debt-will-i-actually-get-into-by-going-to-university $>$

Callon, M. (1991). Techno-Economic Networks and Irreversibility. In Law, J. (ed.) A Sociology of Monsters: Essays on Power, Technology and Domination. London: Routledge, pp132-161.

Clayton, P., and Davies, P. (eds) (2006). The Re-Emergence of emergence: The emergentist hypothesis from science to religion. Oxford: Oxford University Press.

Creanor, L., Gowan, D., Howells C., Trinder K. (2006). The Learner's Voice: a focus on the e-learner experience, in S. Banks, V. Hodgson, C. Jones, B. Kemp, D. McConnell and C. Smith (Eds), Proceedings of the Fifth International Conference on Networked Learning, 10-12 April 2006 Lancaster: Lancaster University. Online HTTP < http://networkedlearningconference.org.uk/past-proceedings/index.htm>

Cutajar, M, and Zenios, M. (2012). Variations in students' experience of networked learning in a postcompulsory pre-university context. In V. Hodgson, C. Jones, M. de Laat, D. McConnell, T. Ryberg, \& P. Sloep, P. Proceedings of the 8th International Conference on Networked Learning, 2-4th April 2012, Maastricht, NL: pp 41-49. Online HTTP < http://networkedlearningconference.org.uk/pastproceedings/index.htm>

De Laat, M., and Lally, V. (2004). Complexity theory and praxis:Researching collaborative learning and tutoring processes in a networked learning community. In Goodyear, P., Banks, S., Hodgson, V., and McConnell, D. Advances in Research on Networked Learning. Dordrecht: Kluwer Academic Publishers, pp 11-42.

Dennett, D.C. (1995). Darwin's Dangerous idea: Evolution and the meanings of life. London: Allen Lane.

Dewey, J. (1916 [1980]). Democracy and education: An introduction to the philosophy of education. In J. A. Boydston (Ed.), Middle works 9. Carbondale, IL: Southern Illinois University Press.

Dohn, N. B. (2014). Implications for networked learning of the 'practice' side of social practice theories - a tacit-knowledge perspective. In Hodgson, V.E., De Laat, M., McConnell, D., and Ryberg, T. (Eds). The Design, Experience and Practice of Networked Learning,pp 29-49. Heidleberg and London: Springer.

Dohn, N.B. (2006). Affordances- a Merleau-Pontian account. In S. Banks, V. Hodgson, C. Jones, B. Kemp, D. McConnell and C. Smith (eds) Proceedings of the Fifth International Conference on Networked Learning 2006. Lancaster: Lancaster University. Online HTTP < http://networkedlearningconference.org.uk/pastproceedings/index.htm>

Elkjaer, B. (2009). Pragmatism: A learning theory for the future. In K. Illeris. Contemporary Theories of Learning: Learning theorists... in their own words. London: Routledge, pp74-89.

Ellis, R., and Goodyear, P. (2010). Students experiences of e-learning in higher education: the ecology of sustainable innovation. New York: Routledge.

Engeström, Y. (2009). Expansive learning: toward an activity-theoretical reconceptualization. In K. Illeris. Contemporary Theories of Learning: Learning theorists... in their own words. London: Routledge, pp59-73.

Proceedings of the 10th International Conference on Networked Learning 2016, Edited by:

Cranmer S, de Laat M, Ryberg T \& Sime, JA. 
Entwistle, N. J., \& Ramsden, P. (1983). Understanding student learning. London: Croom Helm.

Fenwick, T. Edwards, R., and Sawchuk, P. (2011). Emerging Approaches to Educational Research: Tracing the Sociomaterial, London: Routledge.

Fenwick, T. and Edwards, R. (2010). Actor network theory in education. Routledge, London.

Fenwick, T., and Edwards, R. (2011). Introduction: Reclaiming and Renewing Actor Network Theory for Educational Research. Educational Philosophy and Theory, Vol. 43, No. S1, 1-14.

Goodyear, P. (2000). Final Report, Volume 1: Networked Learning in Higher Education Project (JCALT). Online HTTP http://csalt.lancs.ac.uk/jisc/

Goodyear, P. and Carvalho, L. (2014). Introduction: Networked Learning and Learning Networks . In Carvalho, L., and Goodyear (eds). The Architecture of Productive Learning Networks, pp 3-22.London and New York: Routledge.

Goodyear, P, Jones, C, Asensio, M, Hodgson, V \& Steeples, C. (2005). Networked learning in higher education: students' expectations and experiences, Higher Education, Vol 50 No 3 pp 473 - 508.

Haggis, T. (2009). What have we been thinking of? A critical overview of 40 years of student learning research in higher education. Studies in Higher Education, 34: 4, 377-390.

Haggis, T. (2003). Constructing Images of Ourselves? A Critical Investigation into 'Approaches to Learning' Research in Higher Education. British Educational Research Journal, Vol. 29, No. 1,89-104.

Harman, G. (2009). Prince of Networks: Bruno Latour and Metaphysics. Melbourne: Re.press. Online HTTP < http://re-press.org/books/prince-of-networks-bruno-latour-and-metaphysics/ >

Hasselgren, B., \& Beach, D. (1997) Phenomenography-a “good-for-nothing brother” of phenomenology? Outline of an analysis, Higher Education Research \& Development, 16 (2), 191-202.

Hazelkorn, E. (2015). Rankings and the Reshaping of Higher Education: The Battle for World-Class Excellence (2nd Edition). Basingstoke (UK): Palgrave-Macmillan.

Jones, C \& Asensio, M. (2001). Experiences of assessment: using phenomenography for evaluation. Journal of Computer Assisted Learning (JCAL). Vol.17 No.3, pp314 - 321.

Kaptelinin, V. and Nardi, B.A. (2006). Acting with Technology: Activity Theory and Interaction Design. Cambridge, MA: MIT Press.

Latour, B. (2005). Reassembling the social. An Introduction to Actor-Network Theory. London: Routledge.

Lave, J. (1991). Situating learning in communities of practice. In L. Resnick, J. Levine, and S. Teasley (Eds.), Perspectives on socially shared cognition. Washington, DC: APA pp 63-82.

Lave, J. and Wenger, E. (1991) Situated Learning: Legitimate peripheral Participation. Cambridge: Cambridge University Press.

Marton, F. (1994), Phenomenography. In T. Husen and Postlethwaite, T. N. (eds.), The International Encyclopedia of Education Second Edition, Oxford: Pergamon, 4424-9.

Marton, F. and Booth, S. (1997), Learning and Awareness., Mahwah,NJ: Lawrence Erlbaum Associates.

Marton, F. Dall'Alba, G. and Beaty E. (1993). Conceptions of Learning. International Journal of Educational Research, 19, 277-300.

Marton, F., Hounsell, D. and Entwistle, N. (1997). The Experience of Learning: Implications for Teaching and Studying in Higher Education. Edinburgh, Scottish Academic Press.

Oberg, H. Bell, A. (2012). Exploring phenomenology for researching lived experience in Technology Enhanced Learning. In V. Hodgson, C. Jones, M. de Laat, D. McConnell, T. Ryberg, \& P. Sloep, P. Proceedings of the 8th International Conference on Networked Learning, 2-4th April 2012, Maastricht, NL: pp 203-210. Online HTTP < http://networkedlearningconference.org.uk/past-proceedings/index.htm>

Ramsden, P. (2002). Learning to Teach in Higher Education (2nd Edition). London: Routledge.

Sabri, D. (2011). What's wrong with 'the student experience'? Discourse: Studies in the Cultural Politics of Education, 32 (5): 657-667.

Thompson, T., L. (2012). Who's taming who? Tensions between people and technologies in cyberspace communities. . In Dirckinck-Holmfeld L, Hodgson V, and McConnell D. (Eds) Exploring the Theory, Pedagogy and Practice of Networked Learning. New York: Springer pp157-172.

Wenger, E. (1998). Communities of practice: learning, meaning, and identity. Cambridge: Cambridge University Press.

Williams, B. (2016). Digital education governance: An introduction. European Educational Research Journal 2016, Vol. 15(1) 3-13. 